\title{
Treatment of displaced intra-articular calcaneal fractures by ligamentotaxis: current concepts' review
}

\author{
T. Schepers $\cdot$ P. Patka
}

Received: 27 November 2008 / Published online: 19 June 2009

(C) The Author(s) 2009. This article is published with open access at Springerlink.com

\begin{abstract}
Introduction A large variety of therapeutic modalities for calcaneal fractures have been described in the literature. No single treatment modality for displaced intra-articular calcaneal fractures has proven superior over the other. This review describes and compares the different percutaneous distractional approaches for intra-articular calcaneal fractures. The history, technique, anatomical and fracture considerations, limitations and the results of different distractional approaches reported in the literature are reviewed.

Method Literature review on different percutaneous distractional approaches for displaced intra-articular calcaneal fractures.

Results Eight studies in which application of a distraction technique was used for the treatment of calcaneal fractures were identified. Because of the use of different classification, techniques, and outcome scoring systems, a metaanalysis was not possible. A literature review reveals overall fair to poor result in 10-29\% of patients. Ten up to $26 \%$ of patients are unable to return to work after percutaneous treatment of their fracture. A secondary arthrodesis has to be performed in $2-15 \%$ of the cases. Infectious complications occur in $2-15 \%$. Some loss of reduction is reported in 4-67\%.

Conclusion Percutaneous distractional reduction and fixation appears to be a safe technique with overall good results and an acceptable complication rate, compared with other treatment modalities for displaced intra-articular calcaneal fractures. A meta-analysis, based on Cochrane Library
\end{abstract}

T. Schepers $(\square) \cdot$ P. Patka

Department of Surgery, Traumatology, Erasmus MC, University Medical Center Rotterdam, P.O. Box 2040,

Room H822-k, 3000 CA Rotterdam, The Netherlands

e-mail: t.schepers@erasmusmc.nl criteria is not possible, because of a lack of level 1 and 2 trials on this subject.

Keywords Calcaneus $\cdot$ Fracture $\cdot$ Minimal invasive . Percutaneous

\section{Introduction}

For many centuries the treatment of calcaneal fractures has been non-operative and included bandaging and elevation of the foot. The earliest published surgical attempts to reduce displaced fragments of a fractured calcaneus were by means of a pulley device, described by Clark in 1855 $[8,11,31]$. The first open reduction took place in a open fracture by Bell in 1882 [23] and the first open reduction and internal fixation (ORIF) by a lateral approach was performed by Morestin in 1902 [13].

In 1895, the radiographic visualization of fractures was introduced and many different treatment modalities, approaches and salvage procedures have been published since that time [23]. The minimal invasive techniques for the treatment of intra-articular calcaneal fractures have evolved from 1855 to present, but gained less popularity compared with ORIF. Minimal invasive surgery of calcaneal fractures can be divided into percutaneous reduction of fragments by Kirschner-wire leveraging [13, 28, 39, 53], application of external fixators [34, 48, 52], and percutaneous distraction of displaced fragments, thus applying the principle of ligamentotaxis with subsequent percutaneous screw fixation [30, 44].

This literature review deals with the treatment of displaced intra-articular calcaneal fractures (DIACF) by percutaneous distraction and screw fixation. The history of different distractional approaches reported in the literature 
is described, including a technical description, the anatomical and fracture considerations, their limitations, and the clinical outcome obtained.

\section{History}

The first skeletal traction applied for the reduction of a displaced calcaneal fracture was reported by Clark [8]. He described a pulley system, but did not elaborate on this method further. Since then, several techniques and traction devices were developed and applied in the treatment of DIACFs. In the early decades of the twentieth century the distraction methods were applied and were the most widely accepted treatment modality for displaced intra-articular calcaneal fractures [33].

The different distraction techniques can be divided into single-, two- and three-point distraction, using the number of inserted pins as points of skeletal distraction as common denominator.

\section{Single-point distraction}

Various authors described different single-point distraction techniques (Fig. 1). Some used the distraction as the only treatment $[23,51]$, while others used it to assist the reduction by additional interventions [6, 7, 22, 23, 38, 43, 51, 55].

Two-point (linear) distraction

In 1929, Böhler described the technique of closed reduction with a wooden wedge in the footsole, lateral clamp com- pression and traction on the calcaneus with countertraction on the tibia $[4,5]$. Böhler changed this treatment strategy for calcaneal fractures repeatedly, and stopped using the transfixational pin through the tibia because of infectious complications $[4,5,23,35,44]$. Several authors applied the method used by Böhler completely or with (minor) modifications using specially designed traction devices $[1,9,16$, 17, 23, 33, 41, 47] (Fig. 2).

\section{Three-point (triangular) distraction}

Three-point distraction was first introduced by McBride [37], followed by others [21, 26]. These triangular distraction methods were combined and formed the technique described by Forgon and Zadravecz in 1983 [15, 56]. This is currently one of the most frequently applied distraction techniques [29, 46, 54]. The three-point distraction approaches used nowadays differ in the direction of applied traction [14, 21, 26, 29, 37, 46, 54] (Fig. 3).

\section{Biomechanical considerations}

The subtalar joint is surrounded by a strong joint capsule and numerous ligaments, which stabilize the subtalar and ankle joints. The ligaments used in ligamentotaxis between the ankle joint, talus, and calcaneus are the calcaneofibular, the tibiocalcaneal ligament of the deltoid ligament, the talocalcaneal interosseous ligament, cervical and the anterior, lateral, posterior, and medial talocalcaneal ligaments. The plantar and dorsal calcaneonavicular ligaments and the calcaneonavicular portion of the bifurcate ligament are
Fig. 1 Single-point distraction techniques by Foldes [23] (1920; a), Kaess [23] (1922; b), Gillette [22] (c), and Carabba [7] (d)
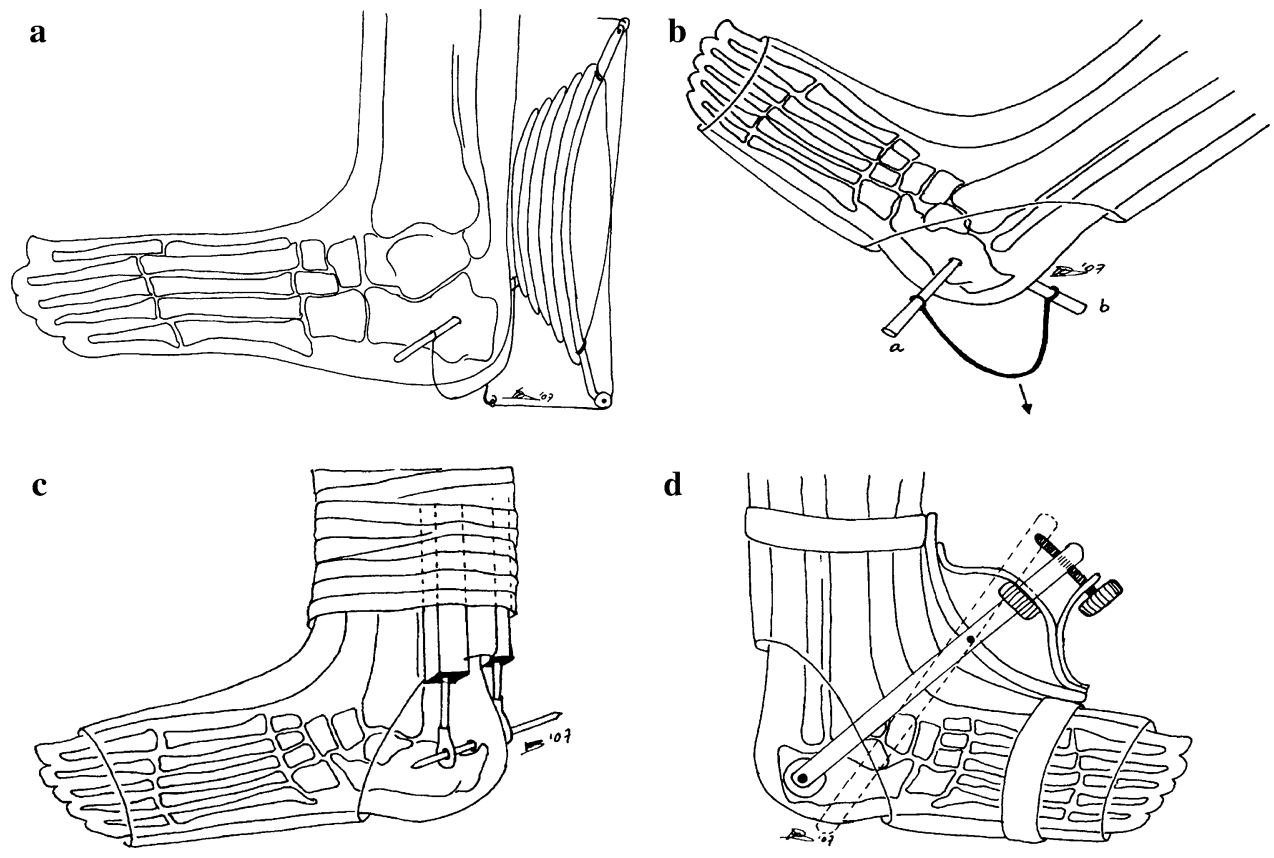

d

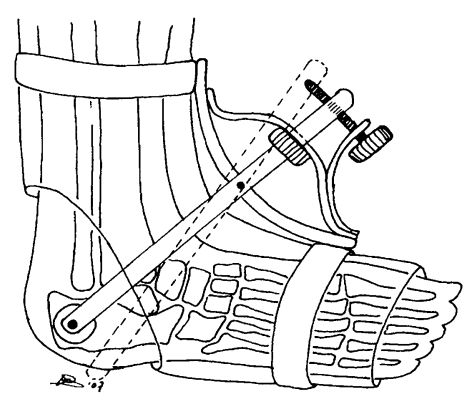


Fig. 2 Two-point distraction techniques by Böhler [4] (1929; a), Conn [9] (b), Olson [41] (c) and Frohlich [17] (d)
Fig. 3 Three-point distraction techniques by Gill [21] (a), McBride [37] (b), Harris [26] (c) and Forgon-Zadravecz [15] $(1983 ; \mathbf{d})$
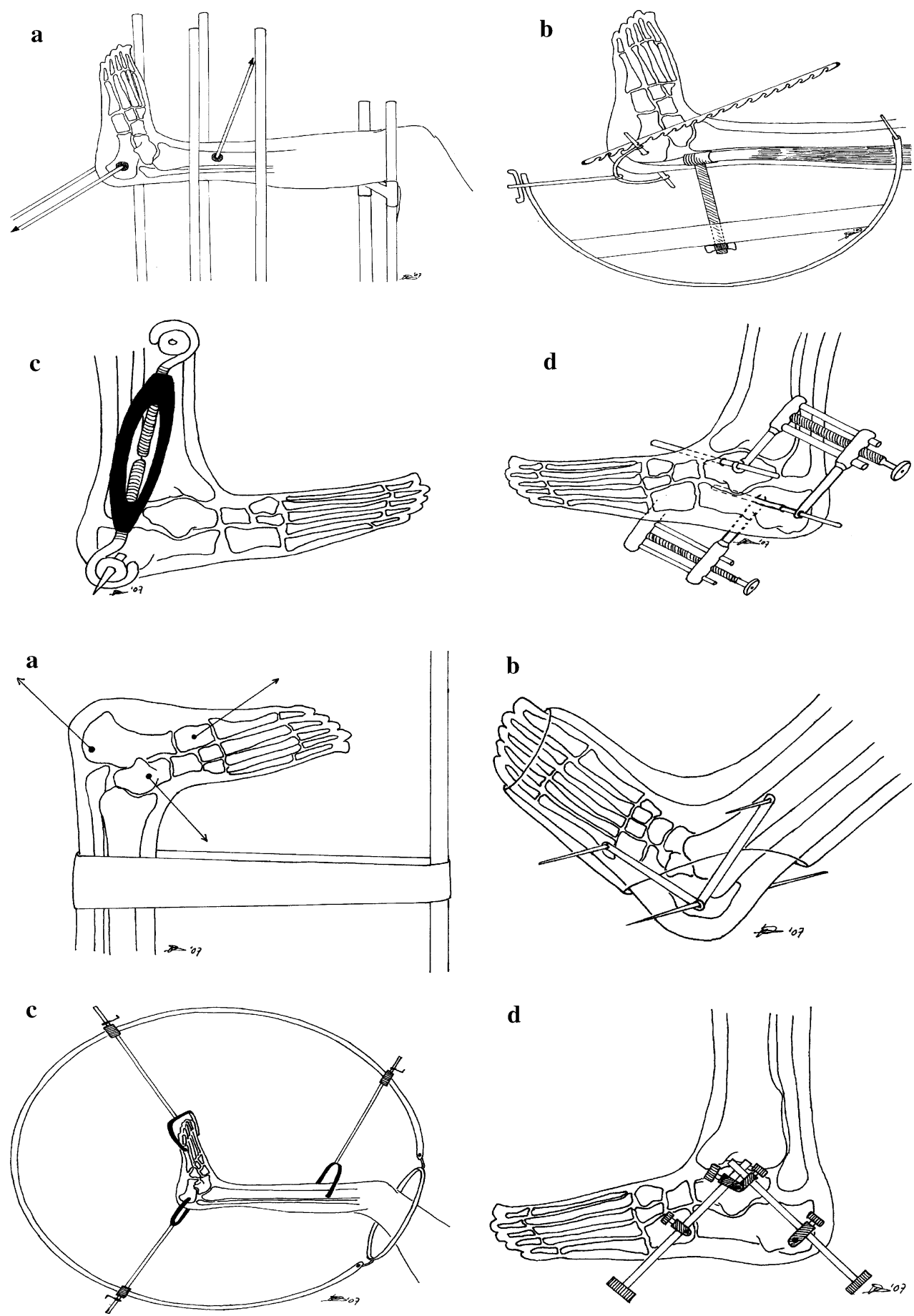

situated between the calcaneus and the navicular bone. The cuboid and calcaneus are connected by the dorsal calcaneocuboid ligament, the short and long plantar ligaments and the calcaneocuboid portion of the bifurcate ligament.

Ligamentotaxis, the indirect reposition of displaced osseous fragments through distraction on the ligaments attached to these fragments, restores the height of the posterior talocalcaneal joint and reduces the varus/valgus malalignment as well as the width of the calcaneal tuberosity.
The lateral joint-fragment usually remains depressed, because the fracture lines run laterally to the interosseous ligament $[20,27]$. This fragment needs to be lifted upwards using Kirschner-wire leveraging or a bone-punch inserted plantarly via the primary fracture line to restore the joint congruence [51].

It has been suggested that only Sanders type II DIACFs would benefit from distractional surgery, but the same has been said for severely comminuted calcaneal fractures, as 
Table 1 Demographics for eight available studies concerning percutaneous distraction techniques

\begin{tabular}{|c|c|c|c|c|c|c|c|c|}
\hline $\begin{array}{l}\text { Study } \\
\text { (evidence level) }\end{array}$ & Trauma & Classification & Surgical treatment & $\mathrm{np} / \mathrm{nf}$ & Age (years) & $\begin{array}{l}\text { Male } \\
(\%)\end{array}$ & FU (months) & Outcome \\
\hline $\begin{array}{l}\text { Walde [55] } \\
\text { Level IV }\end{array}$ & $\begin{array}{l}85 \% \text { Fall } \\
15 \% \text { MVA }\end{array}$ & $\begin{array}{l}\text { Sanders } \\
16 \% \text { Type II } \\
57 \% \text { Type III } \\
27 \% \text { Type IV }\end{array}$ & $\begin{array}{l}\text { 1-Point distraction } \\
\text { (tuberosity }+ \\
\text { K-wire leveraging) }\end{array}$ & $63 / 67$ & $46(18-82)$ & 72 & $68(24-120)$ & $\begin{array}{l}\text { Zwipp } \\
61 \% \text { (Very) good } \\
39 \% \text { Fair-poor }\end{array}$ \\
\hline $\begin{array}{l}\text { Schepers [46] } \\
\text { Level IV }\end{array}$ & $\begin{array}{l}84 \% \text { Fall } \\
16 \% \text { MVA }\end{array}$ & $\begin{array}{l}\text { Sanders } \\
38 \% \text { Type II } \\
28 \% \text { Type III } \\
28 \% \text { Type IV }\end{array}$ & $\begin{array}{l}\text { 3-Point distraction } \\
\text { (tuberosity-cuboid, } \\
\text { tuberosity-talus }+ \\
\text { bone-punch) }\end{array}$ & $50 / 61$ & $46(16-65)$ & 72 & $35(13-75)$ & $\begin{array}{l}\text { AOFAS } \\
36 \% \text { Excellent } \\
36 \% \text { Good } \\
28 \% \text { Fair-poor }\end{array}$ \\
\hline $\begin{array}{l}\text { Stulik [51] } \\
\text { Level IV }\end{array}$ & $\begin{array}{l}96 \% \text { Fall } \\
4 \% \text { Other }\end{array}$ & $\begin{array}{l}\text { Sanders } \\
61 \% \text { Type II } \\
30 \% \text { Type III } \\
9 \% \text { Type IV }\end{array}$ & $\begin{array}{l}\text { 1-Point distraction } \\
\text { (tuberosity }+ \\
\text { K-wire leveraging or } \\
\text { bone-punch) }\end{array}$ & $176 / 205$ & $44(13-67)$ & 85 & $43(25-87)$ & $\begin{array}{l}\text { CN } \\
16 \% \text { Excellent } \\
56 \% \text { Good } \\
28 \% \text { Fair-poor }\end{array}$ \\
\hline $\begin{array}{l}\text { McGarvey [38] } \\
\text { Level IV }\end{array}$ & $\begin{array}{l}32 \% \text { Fall } \\
48 \% \text { MVA } \\
20 \% \text { other }\end{array}$ & $\begin{array}{l}\text { Sanders } \\
32 \% \text { Type II } \\
26 \% \text { Type III } \\
29 \% \text { Type IV }\end{array}$ & $\begin{array}{l}\text { 1-Point distraction } \\
\text { (tuberosity }+ \\
\text { bone-punch) } \\
\text { External fixation }\end{array}$ & $31 / 33$ & $42(19-64)$ & 77 & $25(6-55)$ & $\begin{array}{l}\text { AOFAS } \\
66 \text { points } \\
\quad(42-92)\end{array}$ \\
\hline $\begin{array}{l}\text { Frohlich } \\
\quad(1999)[17] \\
\text { Level III }\end{array}$ & NS & NS & $\begin{array}{l}\text { 2-Point distraction } \\
\quad \text { (talus-tuberosity) }\end{array}$ & NS/94 & NS & NS & NS & $\begin{array}{l}\text { Mod Merle d' } \\
\text { Aubigne } \\
\text { 79\% Good } \\
\text { to excellent }\end{array}$ \\
\hline $\begin{array}{l}\text { Van Loon [54] } \\
\text { Level IV }\end{array}$ & $\begin{array}{l}73 \% \text { Fall } \\
7 \% \text { MVA } \\
20 \% \text { Other }\end{array}$ & $\begin{array}{l}\text { Crosby-Fitzgibbons } \\
\text { 93\% Type II } \\
\text { 7\% Type III }\end{array}$ & $\begin{array}{l}\text { Forgon-Zadravecz } \\
\text { 3-Point distraction } \\
\text { (talus-cuboid, } \\
\text { tuberosity- talus) }\end{array}$ & $15 / 15$ & $44(21-67)$ & 73 & $14(6-26)$ & $\begin{array}{l}\text { CN } \\
27 \% \text { Excellent } \\
47 \% \text { Good } \\
26 \% \text { Fair-poor }\end{array}$ \\
\hline $\begin{array}{l}\text { Kuner [29] } \\
\text { Level IV }\end{array}$ & NS & NS & $\begin{array}{l}\text { 3-Point distraction } \\
\text { (MT1-tuberosity, } \\
\text { tibia-tuberosity) }\end{array}$ & $-/ 45$ & NS & NS & NS & $\begin{array}{l}\text { Merle d'Aubigne } \\
71 \% \text { Good } \\
\text { to excellent }\end{array}$ \\
\hline $\begin{array}{l}\text { Forgon [14] } \\
\text { Level IV }\end{array}$ & NS & $\begin{array}{l}\text { Own classification } \\
30 \% \text { Type I } \\
40 \% \text { Type II } \\
30 \% \text { Type III }\end{array}$ & $\begin{array}{l}\text { 3-Point distraction } \\
\text { (talus-cuboid, } \\
\text { tuberosity-talus) }\end{array}$ & $-/ 265$ & 41 & NS & 12 & $\begin{array}{l}\text { Own score } \\
43 \% \text { Excellent } \\
47 \% \text { Good } \\
10 \% \text { Fair-poor }\end{array}$ \\
\hline
\end{tabular}

MVA motor vehicle accident, $n p$ number of patients, $n f$ number of fractures, $F U$ follow-up, $C N$ Creighton-Nebraska outcome score, $A O F A S$ American Orthopaedic Foot Ankle Society hindfoot score, NS not specified

anatomical reposition would be impossible even when using ORIF [21, 44]. The main benefit of percutaneous reduction and fixation is the protective nature of the technique towards the soft tissues. Only small stab incisions are made in the skin and the fracture haematoma is left in place, thus enhancing fracture healing [50].

\section{Technique}

Depending upon the distraction technique used, one to three Kirschner wires or Steinmann pins are inserted. The universal location, which is always used, is through the calcaneal tuberosity. Additional insertion sites are, depending on the applied technique, the tibia, the talar trochlea, the cuboid or the metatarsal bones. A distracting force is exerted from one distraction point or between two and three distraction points to reproduce the opposite force produced by the impact that caused the fracture. This procedure restores the arch of the foot and realigns the hindfoot, thereby restoring height and width, and reducing varus of the calcaneus.

Additional operative procedures to achieve reduction of fragments and to restore calcaneal anatomy include the Böhler press or clamp to reduce calcaneal widening and subsequent occurrence of impingement beneath the lateral malleolus [1, 4, 9, 16, 47]. Kirschner wires are used for additional leveraging of depressed fragments, especially the lateral joint fragment $[6,15,18,43,51,55]$. A bone punch to unlock and lift up these fragments is preferred by others [46, 51, 54]. Percutaneous insertion of bone graft has been used, but no additional benefit was reported [51].

In order to improve the rate of anatomical fracture reduction, and therefore the overall outcome, several improvements have recently been implemented. The mobile $\mathrm{C}$-arm system SIREMOBIL Iso-C3D enables intraoperative threedimensional reconstructions of fracture reduction of the 
Table 2 Outcome and complication rates after treatment of displaced intra-articular calcaneal fractures with percutaneous distraction techniques

\begin{tabular}{|c|c|c|c|c|c|}
\hline Study & $\begin{array}{l}\text { Fair/poor result } \\
(\%)\end{array}$ & $\begin{array}{l}\text { Unable to work } \\
(\%)\end{array}$ & $\begin{array}{l}\text { Loss of reduction } \\
(\%)\end{array}$ & $\begin{array}{l}\text { Infection } \\
(\%)\end{array}$ & $\begin{array}{l}\text { Arthrodesis } \\
(\%)\end{array}$ \\
\hline Walde [55] & 39 & NS & 1 & 13 & NS \\
\hline Schepers [46] & 28 & 10 & 30 & 15 & 15 \\
\hline Stulik [51] & 28 & 26 & 4.5 & 8.7 & NS \\
\hline McGarvey [38] & NS & NS & NS & 30 & NS \\
\hline Frohlich [17] & 21 & NS & NS & 2.1 & 2.1 \\
\hline Van Loon [54] & 26 & NS & 67 & 13 & NS \\
\hline Kuner [29] & 29 & NS & NS & NS & NS \\
\hline Forgon [14] & 10 & NS & 4.1 & 3.7 & NS \\
\hline
\end{tabular}

$N S$ not specified

joint-surfaces. This was shown to be of value in ORIF of calcaneal fractures [45]. The same holds true for the intraoperative mobile CT-scanning [36]. The use of peroperative subtalar arthroscopy has been applied to obtain anatomic restoration of the posterior talocalcaneal joint, with a positive effect on outcome in retrospective series. $[12,19,32,40,42]$.

\section{Limitations and complications}

Several concerns regarding the effectiveness of distraction techniques have been reported [1, 3, 24]. These include poor results in general, non-anatomical reduction, infectious complications and loss of reduction.

Poor results in general

Bankart reported clinically poor results using Böhler's technique, probably because of the 3 months immobilization in plaster, which resulted in a stiff ankle joint [3]. His opinion was shared by others [24]. Currently, functional aftertreatment is applied shortly after surgery and outcome appears to be more favourable $[15,17,46,51]$.

Non-anatomical reduction

No universal treatment or surgical approach exists that can be applied to treat all fractures of the calcaneus [35]. The question remains whether adequate reduction of displaced intra-articular calcaneal fractures is even possible by closed methods [1]. Assessing the reduction on plain radiographs, by measuring the tuber-joint angle by Böhler, does not ensure a proper restoration of the posterior talocalcaneal facet $[9,10,24]$. As the percutaneous reduction of fractures is indirect, perfect anatomical restoration of the posterior facet anatomy and longitudinal arch of the foot should not be expected $[9,25,30]$. These effects might be amplified by the decrease in viability of the cartilage [2].

\section{Infectious complications}

The minimally invasive techniques were developed to protect the soft-tissues [30, 44, 50], but infectious complications do occur in patients treated percutaneously [46]. The later distraction techniques use screws situated subcutaneously rather than transosseous pins, which has resulted in a lower complication rate [15].

Loss of reduction

Percutaneously placed screws might provide a less rigid fixation of fracture fragments compared with plating, as collapse or loss of the obtained reduction has been reported after percutaneous reduction and subsequent fixation [46, $51,54]$. One study showed a similar strength of plating versus percutaneous screw fixation in Sanders type 2B fractures [49].

\section{Literature review}

A literature search was conducted in the electronic databases of Embase, Cochrane Library and PubMed using the following search-terms and Boolean operators: ('calcaneus' OR 'os calcis' OR 'calcaneum' OR 'calcaneal') AND 'fracture' AND ('percutaneous' OR 'minimally invasive') up to November 2008. Manuscripts were reviewed by both authors. Manuscripts were considered eligible if treatment of displaced intra-articular calcaneal fractures by traction was used. In addition, the reference lists of these manuscripts were checked to find additional studies. Studies from 1990 and forward were selected, as these made better use of outcome scoring systems and computed tomography (CT) classifications.

In total, two review articles were identified [30, 44], and eight retrospective case series were included [14, 17, 29, $38,46,51,54,55]$. The level of evidence, as suggested by the Cochrane Collaboration, was level IV (non-randomized 
series of patients compared with previous or historical controls) for cohort studies.

Considerable differences were found in these eight studies (Table 1) [14, 17, 29, 38, 46, 51, 54, 55]. There is a large variety in the number of treated fractures (15-265 fractures), amount of open fractures, the type of classification used, the severity of the fractures, the average duration of follow-up (12-68 months), and the outcome scoring applied. This makes the comparison of this data in a systematic review impossible.

Table 2 shows an overview of data on outcome and complications as mentioned in the eight studies included. A fair to poor result was seen in 10-39\% of patients; $26 \%$ on average. Ten up to $26 \%$ of patients with a calcaneal fracture were unable to return to work. Considering complications encountered; a secondary arthrodesis was performed in $2-15 \%$, infections occurred in $2-30 \%$, and a loss of reduction was reported in 4-67\% [14, 17, 29, 46, 51, 54, 55].

To date, no randomized trial comparing the percutaneous distractional technique with ORIF or conservative treatment of intra-articular calcaneal fractures has been reported. In one study, two retrospective series of open and percutaneously treated patients were compared. This study revealed a favourable outcome and low complication rate for the percutaneously treated group [17].

\section{Conclusion}

The percutaneous approach with the use of distractional force is the oldest operative treatment for intra-articular calcaneal fractures. A total of eight studies were identified in the literature. Because of large differences in these studies, and the lack of randomized trials in which the percutaneous techniques are evaluated, a meta-analysis was impossible. However, overall treatment outcome was good in most studies. One study showed improved outcome in percutaneously treated patients compared to patients treated with ORIF.

Open Access This article is distributed under the terms of the Creative Commons Attribution Noncommercial License which permits any noncommercial use, distribution, and reproduction in any medium, provided the original author(s) and source are credited.

\section{References}

1. Arnesen A (1958) Fracture of the os calcis and its treatment. II. A contribution to the discussion on the treatment of calcaneus fracture based on an analysis of a ten-year material treated by closed reduction and traction, from Sentralsykehuset i Trondheim. Acta Chir Scand 15(Suppl 234):1-51

2. Ball ST, Jadin K, Allen RT, Schwartz AK, Sah RL, Brage ME (2007) Chondrocyte viability after intra-articular calcaneal fractures in humans. Foot Ankle Int 28(6):665-668
3. Bankart ASB (1942) Fractures of the os calcis. Lancet 240(6207): 175

4. Böhler L (1931) Diagnosis, pathology and treatment of fractures of the os calcis. J Bone Joint Surg 13:75-89

5. Böhler L (1957) Die Technik der Knochenbruchbehandlung. Verlag Wilhelm Maudrich, Wien Band II, pp 2148-2217

6. Buch J, Blauensteiner W, Scherafati T, Vischer HM, Fischer W (1989) [Conservative treatment of calcaneus fracture versus repositioning and percutaneous bore wire fixation. A comparison of 2 methods]. Unfallchirurg 92(12):595-603

7. Carabba V (1936) Apparatus for treatment of fractured os calcis. Am J Surg 33(1):53-59

8. Clark LG (1855) Fracture of the os calcis. Lancet 65(1651):403404

9. Conn HR (1935) The treatment of fractures of the os calcis. J Bone Joint Surg Am 17(2):392-405

10. Dunlop J (1940) The traction treatment of fractures of the os calcis. Surg Gynec Obst 70:408-412

11. Eastwood DM, Phipp L (1997) Intra-articular fractures of the calcaneum: why such controversy? Injury 28(4):247-259

12. Elgafy H, Ebraheim NA (1999) Subtalar arthroscopy for persistent subfibular pain after calcaneal fractures. Foot Ankle Int 20(7):422-427

13. Essex-Lopresti P (1952) Mechanism, reduction technique and results in fractures of os calcis. Br J Surg 39:395-419

14. Forgon M (1993) Closed reduction and percutaneous osteosynthesis: Technique and results in 265 calcaneal fractures. In: Tscherne $\mathrm{H}$, Schatzker J (eds) Major fractures of the pilon, the talus, and the calcaneus. Springer-Verlag, New York, pp 207-213

15. Forgon M, Zadravecz G (1999) Die Kalkaneusfraktur. Springer, Berlin, pp 1-104

16. Forrester CRG (1934) Acute fractures of the os calcis. Am J Surg 25:404-413

17. Frohlich P, Zakupszky Z, Csomor L (1999) [Experiences with closed screw placement in intra-articular fractures of the calcaneus. Surgical technique and outcome]. Unfallchirurg 102(5):359364

18. Fujii T, Takakura Y, Tanaka Y, Kitada C (2004) Surgical tip: manipulation of closed pinning for intraarticular calcaneal fracture. Foot Ankle Int 25(9):685-686

19. Gavlik JM, Rammelt S, Zwipp H (2002) Percutaneous, arthroscopically-assisted osteosynthesis of calcaneus fractures. Arch Orthop Trauma Surg 122(8):424-428

20. Giachino AA, Uhthoff HK (1989) Intra-articular fractures of the calcaneus. J Bone Joint Surg Am 71(5):784-787

21. Gill GG (1944) A three pin method for treatment of severely comminuted fractures of the os calcis. Surg, Gynec and Obstet 78:653-656

22. Gillette E (1930) An apparatus for treatment of fractures of the os calcis. J Bone Joint Surg Am 12:670-671

23. Goff C (1938) Fresh fractures of the os calcis. Arch Surg 36:744765

24. Gray CH (1942) Crush fractures of the os calcis. Lancet 239(6178):106-108

25. Harding M (1926) Os calcis fracture, a new method of reduction. J Bone Joint Surg Am 8:720-722

26. Harris RI (1946) Fractures of the os calcis; their treatment by triradiate traction and subastragalar fusion. Ann Surg 124:10821100

27. Herzenberg JE (1986) CT of calcaneal fractures. AJR Am J Roentgenol 146(3):644-645

28. King RE (1973) Axial pin fixation of fractures of the Os calcis (method of Essex-Lopresti). Orthop Clin North Am 4(1):185-188

29. Kuner EH, Bonnaire F, Hierholzer B (1995) [Classification and osteosynthesis technique of calcaneus fractures. External fixator as temporary distractor]. Unfallchirurg 98(6):320-327 
30. Levine DS, Helfet DL (2001) An introduction to the minimally invasive osteosynthesis of intra-articular calcaneal fractures. Injury 32(Suppl 1):SA51-SA54

31. Lindsay WR, Dewar FP (1958) Fractures of the os calcis. Am J Surg 95(4):555-576

32. Lui TH (2006) Arthroscopic subtalar release of post-traumatic subtalar stiffness. Arthroscopy 22(12):1364 e1-1364 e4

33. MacAusland W (1941) The treatment of comminuted fractures of the os calcis. Surg Gynec Obst 73:671-675

34. Magnan B, Bortolazzi R, Marangon A, Marino M, Dall'Oca C, Bartolozzi P (2006) External fixation for displaced intra-articular fractures of the calcaneum. J Bone Joint Surg Br 88(11):14741479

35. Magnuson PB, Stinchfield F (1938) Fracture of the os calcis. Am J Surg 42:685-692

36. Mayr E, Hauser H, Ruter A, Bohndorf K (1999) [Minimally invasive intraoperative CT-guided correction of calcaneal osteosynthesis]. Unfallchirurg 102(3):239-244

37. McBride E (1944) Fractures of the os calcis; tripod-pin-traction apparatus. J Bone Joint Surg 26(3):578-579

38. McGarvey WC, Burris MW, Clanton TO, Melissinos EG (2006) Calcaneal fractures: indirect reduction and external fixation. Foot Ankle Int 27(7):494-499

39. Nakaima N, Yamashita H, Tonogai R, Ikata T (1983) A technique of dynamic reduction for displaced fractures of the thalamus of the calcaneum. Int Orthop 7(3):185-190

40. Nehme A, Chaminade B, Chiron P, Fabie F, Tricoire JL, Puget J (2004) [Percutaneous fluoroscopic and arthroscopic controlled screw fixation of posterior facet fractures of the calcaneus]. Rev Chir Orthop Reparatrice Appar Mot 90(3):256-264

41. Olson P (1939) The treatment of fractures of the os calcis. J Bone Joint Surg Am 21:747-751

42. Parisien JS, Vangsness T (1985) Arthroscopy of the subtalar joint: an experimental approach. Arthroscopy 1(1):53-57

43. Poigenfurst J, Buch J (1988) [Treatment of severe fractures of the calcaneus by reposition and percutaneous bore wire fixation]. Unfallchirurg 91(11):493-501

44. Rammelt S, Amlang M, Barthel S, Zwipp H (2004) Minimallyinvasive treatment of calcaneal fractures. Injury 35(Suppl 2):SB55-SB63
45. Rubberdt A, Feil R, Stengel D, Spranger N, Mutze S, Wich M, Ekkernkamp A (2006) [The clinical use of the ISO-C(3D) imaging system in calcaneus fracture surgery]. Unfallchirurg 109(2):112118

46. Schepers T, Schipper IB, Vogels LM, Ginai AZ, Mulder PG, Heetveld MJ, Patka P (2007) Percutaneous treatment of displaced intra-articular calcaneal fractures. J Orthop Sci 12(1):22-27

47. Schofield R (1936) Fractures of the os calcis. J Bone Joint Surg Am 18:566-580

48. Schwall R, Junge RH, Zenker W, Besch L (2000) [Treatment of intra-articular calcaneus fractures with a para-articular external fixator]. Unfallchirurg 103(12):1065-1072

49. Smerek JP, Kadakia A, Belkoff SM, Knight TA, Myerson MS, Jeng CL (2008) Percutaneous screw configuration versus perimeter plating of calcaneus fractures: a cadaver study. Foot Ankle Int 29(9):931-935

50. Stein H, Rosen N, Lerner A, Kaufman H (2003) Minimally invasive surgical techniques for the reconstruction of calcaneal fractures. Orthopedics 26(10):1053-1056

51. Stulik J, Stehlik J, Rysavy M, Wozniak A (2006) Minimallyinvasive treatment of intra-articular fractures of the calcaneum. J Bone Joint Surg Br 88(12):1634-1641

52. Talarico LM, Vito GR, Zyryanov SY (2004) Management of displaced intraarticular calcaneal fractures by using external ring fixation, minimally invasive open reduction, and early weightbearing. J Foot Ankle Surg 43(1):43-50

53. Tornetta P 3rd (1998) The Essex-Lopresti reduction for calcaneal fractures revisited. J Orthop Trauma 12(7):469-473

54. Van Loon C, Roumen R (1997) Percutane repositie en fixatie van gedisloceerde intra-articulaire calcaneusfracturen: ervaringen bij de eerste vijftien patiënten. Ned Tijdschr Trauma 2:31-37

55. Walde TA, Sauer B, Degreif J, Walde HJ (2008) Closed reduction and percutaneus Kirschner wire fixation for the treatment of dislocated calcaneal fractures: surgical technique, complications, clinical and radiological results after 2-10 years. Arch Orthop Trauma Surg 128(6):585-591

56. Zadravecz G, Szekeres P (1984) [Late results of our treatment method in calcaneus fractures]. Aktuelle Traumatol 14(5):218 226 